\title{
Analisis Daya Dukung Dan Penurunan Pondasi Tiang Pancang Proyek Gedung DPRD Kabupaten Pemalang
}

\author{
Amris Azizi $^{(1)}$, M. Agus Salim ${ }^{(2)}$, Gilang Ramadhon ${ }^{(3)}$ \\ ${ }^{(1,2,3)}$ Program Studi Teknik Sipil Fakultas Teknik dan Sains, Universitas Muhammadiyah Purwokerto
}

\begin{abstract}
Abstrak
Pondasi merupakan bagian penting dari suatu bangunan yang berfungsi memikul beban bangunan dan beban lainnya dan meneruskannya ke dalam tanah sampai ke lapisan atau kedalaman tertentu. Dalam perencanaan pondasi terlebih dahulu harus dihitung dan ditentukan kapasitas dukung rencana. Hal lain yang penting diperhitungkan adalah besarnya penurunan pondasi. Tujuan dari penelitian ini adalah menganalisis daya dukung dan penurunan pondasi tiang pancang pada proyek gedung DPRD Kabupaten Pemalang. Penelitian dilakukan dengan menganalisis data berupa hasil uji test SPT dan shop drawing. Berdasarkan hasil analisis didapat seluruh pondasi tiang pancang mampu menahan beban yang bekerja diatasnya, sehingga pondasi dikategorikan aman (Qall > Pp). Dengan perbandingan dari beban terbesar pada pondasi tipe 1 sebesar 145,727 ton > 49,962 ton, pondasi tipe 2 sebesar 290,710 ton > 107,077 ton, pondasi tipe 3 sebesar 579,930 ton $>380,931$ ton dan pondasi tipe 4 sebesar 727,396 ton $>489,773$ ton. Penurunan yang terjadi pada pondasi sedalam $0,029 \mathrm{~m}$ atau lebih kecil dari penurunan ijinnya yaitu sebesar $10 \%$ diameter.
\end{abstract}

Kata kunci : Daya Dukung, Penurunan, Pondasi, Tiang Pancang.

\section{PENDAHULUAN}

Struktur bawah dari suatu bangunan lazim disebut pondasi, pondasi ini bertugas meletakkan bangunan dan meneruskan beban bangunan atas (upper structure/super structure) ke dasar tanah yang cukup kuat mendukungnya. Dalam perencanaan pondasi harus mempertimbangkan beberapa persyaratan, yaitu : daya dukung tanah harus mampu menerima beban dari pondasi, pondasi harus cukup kuat untuk mencegah penurunan (settlement) dan perputaran (rotasi) yang berlebihan, tidak terjadi penurunan setempat yang terlalu besar bila dibandingkan dengan penurunan pondasi di dekatnya, dan aman terhadap bahaya guling. Oleh karena itu analisis mengenai daya dukung pondasi penting dilakukan karena apabila kekuatan tanah tidak mampu memikul beban pondasi maka penurunan yang berlebihan atau keruntuhan tanah akan terjadi.

Penelitian ini akan menganalisis daya dukung dan penurunan pondasi proyek pembangunan Gedung DPRD Kabupaten Pemalang. Proyek ini menggunakan pondasi tiang pancang. Gedung ini terdiri dari 6 (enam) lantai dengan konstruksi beton bertulang dan konstruksi atap rangka baja.

\section{METODOLOGI}

Penelitian ini menggunakan data sekunder berupa shop drawing Proyek Gedung DPRD Kabupaten Pemalang dan data hasil uji tanah. Shop drawing dipakai untuk mengetahui tipe pondasi dan jumlah tiang pada setiap kolom. Hasil uji tanah (SPT) digunakan untuk menganalisis dan menghitung kapasitas dukung dan penurunan pondasi. Pembebanan pondasi didapat dari analisis dan perhitungan struktur menggunakan SAP 2000.

Analisis daya dukung dan penurunan pondasi dilakukan dengan Metode Meyerhof dan Vesic.

Daya dukung ujung tiang

$$
Q p=40 \times N S P T \times A p
$$

$$
\begin{aligned}
& \text { Dengan : } \\
& \mathrm{Qp} \quad=\text { Daya dukung ujung tiang (ton) } \\
& \mathrm{Ap}=\text { Luas penampang }\left(\mathrm{m}^{2}\right) \\
& \mathrm{NSPT}=\text { Nilai perlawanan terhadap SPT }
\end{aligned}
$$

Daya dukung selimut tiang untuk tanah kohesif :

$$
Q s=0,5 N S P T \times p \times \Delta L
$$

Sedangkan untuk tanah non-kohesif (Qs) yakni sebesar :

$$
Q s=0,3 N S P T \times p \times \Delta L
$$

Dengan :

Qs = Daya dukung selimut tiang (ton)

$\mathrm{p} \quad=$ Keliling tiang $(\mathrm{m})$

$\Delta \mathrm{L}=$ Panjang tiang $(\mathrm{m})$

Daya Dukung Ultimit Tiang

$Q u=Q p+Q s$

Dengan :

$\mathrm{Qu}=$ Daya dukung ultimit tiang (ton) 
Qp = Daya dukung ujung tiang (ton)

Qs = Daya dukung selimut tiang (ton)

Penurunan Tiang Tunggal

$\mathrm{S}=\mathrm{S} 1+\mathrm{S} 2+\mathrm{S} 3$

Dengan,

$\mathrm{S}=$ Penurunan tiang tunggal,

$\mathrm{S} 1=$ Penurunan batang tiang,

S2 =Penurunan tiang akibat beban titik,

S3 = Penurunan akibat beban yang tersalur sepanjang batang.

$$
S 1=\frac{(Q w p+\varepsilon Q w s) \times L}{A p \times E p}
$$

Dengan,

Qwp = Bahan yang dipikul ujung tiang dibawah kondisi beban kerja $(\mathrm{Qb} / \mathrm{F})(\mathrm{kN})$,

Qws = Beban yang dipikul kulit tiang dibawah kondisi beban kerja $(\mathrm{Q} / \mathrm{F})(\mathrm{kN})$,

Ap = Luas penampang tiang,

$\mathrm{L} \quad=$ Panjang tiang $(\mathrm{m})$,

Ep = Modulus bahan tiang.

$$
S 2=\frac{Q w p \times C p}{D \times q p}
$$

Dengan,

$\mathrm{Cp}=$ Koefisien empiris

qp $=$ Tahanan ujung batas tiang

$$
S 3=\frac{Q w p \times C s}{L \times A p} . \text { Dengan, }
$$

$\mathrm{Cs}=$ konstanta empiris $=\left(0,93+0,16 \sqrt{\frac{L}{D}}\right) \times C P$

\section{HASIL DAN PEMBAHASAN}

\subsection{Data Tanah}

Kondisi tanah yang diperoleh dari laporan hasil penyelidikan tanah tim laboratorium mekanika tanah Fakultas Teknik Universitas Diponegoro dengan tes SPT (Standard Penetration Test) adalah sebagi berikut :

Tabel 1. Hasil Uji SPT (BH. 1)

\begin{tabular}{ccc}
\hline Kedalaman $(\mathbf{m})$ & Jenis Tanah & N-SPT \\
\hline $0,00-2,00$ & Lempung & 17 \\
$2,00-4,00$ & Lempung & 6 \\
$4,00-6,00$ & Lempung & 21 \\
$6,00-8,00$ & Lanau & 25 \\
$8,00-10,00$ & Lempung & 39 \\
$10,00-12,00$ & Pasir & 40 \\
$12,00-14,00$ & Pasir & 29 \\
$14,00-16,00$ & Pasir & 31 \\
$16,00-18,00$ & Pasir & 32
\end{tabular}

\begin{tabular}{lll}
$18,00-20,00$ & Pasir & 34 \\
$20,00-22,00$ & Pasir & 37 \\
$22,00-24,00$ & Pasir & 39 \\
$24,00-26,00$ & Pasir & 42 \\
$26,00-28,00$ & Pasir & 52 \\
$28,00-30,00$ & Pasir & 56 \\
\hline
\end{tabular}

Sumber : Hasil Uji SPT, 2019

\subsection{Data Struktur}

Pondasi tiang pancang dengan penampang lingkaran diameter $0,35 \mathrm{~m}$ sepanjang 10 meter dan sebanyak 228 buah dengan mutu beton K-350. Tipe pondasi berdasarkan jumlah pondasi dalam pile capnya, yaitu :

Tabel 2. Data tipe pondasi

\begin{tabular}{cc}
\hline Tipe Pondasi & Jumlah Pondasi \\
\hline P1 & 1 \\
P2 & 2 \\
P3 & 4 \\
P4 & 5 \\
\hline Sumber : Gambar Struktur, 2019
\end{tabular}

\subsection{Analisis Distribusi Gaya Pada Tiang}

Analisis distribusi gaya pada tiang dilakukan dengan menggunakan program komputer struktur dan analisis SAP2000. Beban aksial hasil analisis melalui SAP2000 adalah sebagai berikut :

$\begin{array}{ccc}\text { Tabel 3. Beban Aksial Pondasi } \\ \text { Tipe } & \text { Jumlah } & \text { Beban Aksial (Pp) } \\ \text { Pondasi } & \text { Pondasi } & \text { (ton) } \\ \text { P1 } & 1 & 49,962 \\ \text { P2 } & 2 & 107,077 \\ \text { P3 } & 4 & 380,931 \\ \text { P4 } & 5 & 489,717\end{array}$

Sumber : Analisis Perhitungan, 2020

\subsection{Analisis Daya Dukung}

Daya dukung tiang tunggal dan kelompok tiang dianalisis dengan Metode Meyerhof 1956. Hasil analisis terlihat dalam Tabel 4.

Hasil analisis diatas memperlihatkan bahwa nilai daya dukung pondasi yang diperkenankan (aman) Qall tiang tunggal maupun kelompok (Qug) tiang lebih besar dari beban aksial (Pp). Dengan demikian pondasi aman terhadap beban aksial yang bekerja.

\subsection{Analisis Penurunan Tiang Tunggal}

Hasil perhitungan penurunan pondasi tiang tunggal diameter 0,35 meter pada kedalaman $10 \mathrm{~m}$ didapat sebesar 0,029 m. Berdasarkan penurunan ijin $10 \%$ dari diameter, maka persyaratan penurunan tiang tunggal memenuhi $\left(\mathrm{S}<\mathrm{S}^{\mathrm{ijin}}\right)$. 
Tabel 4. Daya Dukung Pondasi Tunggal dan Kelompok

\begin{tabular}{ccccccc}
\hline $\begin{array}{c}\text { Tipe } \\
\text { Pondasi }\end{array}$ & $\begin{array}{c}\text { Qp } \\
\text { (ton) }\end{array}$ & $\begin{array}{c}\text { Qs } \\
\text { (ton) }\end{array}$ & $\begin{array}{c}\text { Qu }= \\
\mathbf{Q p + Q s} \\
\text { (ton) }\end{array}$ & $\begin{array}{c}\text { Qall }= \\
\text { Qu/2,5 } \\
\text { (ton) }\end{array}$ & $\begin{array}{c}\text { Efisiensi } \\
\text { kelompok } \\
\text { tiang }\end{array}$ & $\begin{array}{c}\text { Qug } \\
\text { (kelompok } \\
\text { tiang) } \\
\text { (ton) }\end{array}$ \\
\hline P1 & 150,014 & 214,305 & 364,319 & 145,727 & 1 & 364,319 \\
P2 & 150,014 & 214,305 & 364,319 & 290,710 & 0,997 & 726,7749 \\
P3 & 150,014 & 214,305 & 364,319 & 579,930 & 0,995 & 1449,826 \\
P4 & 150,014 & 214,305 & 364,319 & 727,396 & 0,998 & 1818,489 \\
\hline
\end{tabular}

Sumber : Analisis Perhitungan, 2020

\subsection{Analisis Penurunan Tiang Tunggal}

Hasil perhitungan penurunan pondasi tiang tunggal diameter 0,35 meter pada kedalaman $10 \mathrm{~m}$ didapat sebesar $0,029 \mathrm{~m}$. Berdasarkan penurunan ijin $10 \%$ dari diameter, maka persyaratan penurunan tiang tunggal memenuhi $\left(S<\mathrm{S}^{\mathrm{ijin}}\right)$.

\section{Kesimpulan}

Berdasarkan hasil analisis daya dukung dan penurunan pondasi tiang pancang pada proyek pembangunan Gedung DPRD Kabupaten Pemalang dapat diambil kesimpulan (a)Daya dukung ijin tiang tunggal ultimit maupun kelompok tiang mampu menahan beban aksial yang ada diatasnya (Qall > $\mathrm{Pp}$ ), (b)Penurunan pondasi tiang tunggal diameter 0,35 meter dengan kedalaman $10 \mathrm{~m}$ sebesar $0,029 \mathrm{~m}$, masih dibawah penurunan yang diijinkan.

\section{Daftar Pustaka}

Andayana, A. 2016. Analisis Perbandingan Daya Dukung Tiang Pancang Berdasarkan Uji SPT dan Daya Dukung Tiang Pancang Berdasarkan Alat HSPD 120 T. Lampung: Universitas Lampung.

Bowles, J. E. 1993. Analisis dan Disain Pondasi 2, Edisi Keda. Erlangga, Jakarta.

Fatnanta, F. 2018. Bearing Capacity Analysis of Helical Pile Foundation on Peat.Journal MATEC Web Conferences 195.

Hardiyatmo, H. C. 2014. Analisis dan Perancangan Fondasi I. (Edisi Ketiga).Gadjah Mada University Press. Yogyakarta

Hardiyatmo, H. C.2015. Analisis dan Perancangan Fondasi II. (Edisi Ketiga). Gadjah Mada University Press. Yogyakarta

Hardiyatmo, H. C. 2010. Mekanik Tanah II. (Edisi Ketiga). Gadjah Mada University Press. Yogyakarta

Kim, S. 2017. Pile Foundation Design Through the Increased Bearing Capacity of Extended End Pile. Journal of Asian Architecture and Building Engineering, 05 : 402.

Luthfiani, F. 2017. Analisis Penurunan Bangunan Pondasi Tiang Pancang dan Rakit pada Proyek Pembangunan Apartemen Surabaya
Central Business District. Jurnal Karya Teknik Sipil Universitas Diponegoro, 6(2) : 166-179.

Sardjono, H. S. 1988. Pondasi Tiang Pancang. (Jilid I). Sinar Jaya Wijaya. Surabaya

Yandi, A. 2017. Analisis Daya Dukung dan Penurunan Pondasi Tiang Pancang Menggunakan Data N-SPT dan Data Sondir Diverifikasi dengan Hasil Uji PDA (Pile Driving Analyzer) dan CAPWAP (Kasus Proyek Dermaga di Belinyu). Universitas Bangka Belitung. Bangka Belitung

Yusti, A. 2014. Analisis Daya Dukung Pondasi Tiang Pancang Diverifikasi dengan Hasil Uji Pile Driving Analyzer Test dan CAPWAP (Studi Kasus Proyek Pembangunan Gedung Kantor Bank Sumsel Babel di Pangkalpinang). Jurnal Fropil Universitas Bangka Belitung, Vol 2: 1. 